\title{
Growth Factor Receptor Gene
}

National Cancer Institute

\section{Source}

National Cancer Institute. Growth Factor Receptor Gene. NCI Thesaurus. Code C26131.

A class of genes that encode cell surface proteins that bind to extracellular polypeptide molecules triggering intracellular signaling pathways that activate various cellular responses such as cell proliferation and/or differentiation. ( $\mathrm{NCl}$ ) 